\title{
Nitrosation of aspartic acid, aspartame, and glycine ethylester. Alkylation of 4-( $p$-nitrobenzyl)pyridine (NBP) in vitro and binding to DNA in the rat
}

\author{
I. Meier, S.E. Shephard and W.K. Lutz \\ Institute of Toxicology, Swiss Federal Institute of Technology and University of Zurich, CH-8603 Schwerzenbach (Switzerland)
}

(Accepted 12 October 1989)

Keywords: Nitrosation; Alkylation; Amino acids; DNA binding

\section{Summary}

In a colorimetric assay using 4-( $p$-nitrobenzyl)pyridine (NBP) as a nucleophilic scavenger of alkylating agents, the nitrosation and alkylation reactions were investigated for a number of amino acids and derivatives. The alkylating activity increased with the square of the nitrite concentration. The nitrosation rate constants for aspartic acid, aspartame, and glycine ethylester (=precursors $\mathrm{C}$ ) were $0.08,1.4$ and $\leqslant 0.2$, respectively, expressed in terms of the pH-dependent $k_{2}$ rate constant of the equation $\mathrm{dNOC} / \mathrm{dt}=$ $k_{2} \cdot[\mathrm{C}] \cdot[\text { nitrite] }]^{2}$. The rates correlated inversely with the basicity of the amino group. The stability of the alkylating activity was astonishingly high, both in acid and at neutral $\mathrm{pH}$. Half-lives of 500,200 , and 30 min were determined for aspartic acid ( $\mathrm{pH} 3.5$ ), aspartame ( $\mathrm{pH} 2.5$ ), and glycine ethylester ( $\mathrm{pH} 2.5$ ). Values of 60,15 , and $2 \mathrm{~min}$, respectively, were found at $\mathrm{pH} 7$. It is concluded that rearrangement of the primary $N$-nitroso product to the ultimate alkylating agent could be rate-limiting. The potential of nitrosated $\alpha$-amino acids to bind to DNA in vivo was investigated by oral gavage of radiolabelled glycine ethylester to rats, followed immediately by sodium nitrite. DNA was isolated from stomach and liver and analysed for radioactivity and modified nucleotides. No indication of DNA adduct formation was obtained. Based on an estimation of the dose fraction converted from glycine ethylester to the nitroso product under the given experimental conditions, the maximum possible DNA-binding potency of nitroso glycine ethylester is about one order of magnitude below the methylating potency of $N$-nitrosomethylurea in rat stomach. The apparent discrepancy to the in vitro data could be due to efficient detoxification processes in mammalian cells.

Correspondence: Dr. W.K. Lutz, Institute of Toxicology, Swiss Federal Institute of Technology and University of Zurich, CH-8603 Schwerzenbach (Switzerland).

Abbreviations: NOC, nitroso compound; C, nitrosatable precursor; GlyEE, glycine ethylester; NaP, sodium phosphate buffer; NBP, 4-( $p$-nitrobenzyl)pyridine; dNp, deoxyribonucleoside-3'-phosphate.
Endogenous nitrosation of primary amino groups has received scant attention because it is often assumed that rearrangement and decay of the resulting $N$-nitroso compounds (NOC) occur so rapidly that all alkylation reactions take place at the site of nitrosation, e.g. in the stomach lumen. Intracellular DNA, the target for mutagenesis and carcinogenesis, was considered to be an 
unlikely target. However, methylamine has been shown to produce 7-methylguanine in DNA isolated from the stomach of rats after administration of radiolabelled methylamine together with high levels of nitrite (Huber and Lutz, 1984). It was therefore considered worth while to investigate in more detail the kinetics of formation, stability, and alkylating activity of nitrosated primary amino groups. With respect to dietary intake, amino acids and peptide N-terminals constitute major sources of primary amino groups in the stomach (Shephard et al., 1987b). In vitro, a high overall alkylating and mutagenic potency of nitrosated amino acids and peptides was reported (Shephard et al., 1987a), but it is difficult to derive kinetic data from these experiments. Some information is available on the reactivity of diazo compounds formed from the nitrosated amino acids after rearrangement (Warthesen et al., 1975; Brambilla et al., 1979; Pollock, 1985; Tricker and Preussmann, 1986; Challis et al., 1987). However, the effect of the side chain on the preceding steps is not known. In this report, the nitrosation of amino acids and derivatives, including the artificial sweetener aspartame, is investigated in vitro in order to determine the rate of nitrosation. The alkylating activity is studied with a model nucleophile and the stability of the alkylating activity is determined at different $\mathrm{pH}$ values. With one precursor, glycine ethylester, a DNA-binding study in rats is performed so that in vitro and in vivo data can be compared.

\section{Materials and methods}

\section{NBP test}

\section{Chemicals}

Aspartic acid (biochemical standard) was obtained from Serva, aspartame (aspartyl-phenylalanine methyl ester) from Aldrich, sodium nitrite (highest purity) from Fluka. 4-( $p$-Nitrobenzyl)pyridine (NBP), iodomethane, iodoacetic acid and triethylamine were from Merck (for synthesis). All other chemicals were of analytical purity and were purchased from Merck. Absorbance measurements were performed on an Hewlett Packard 8452 spectrophotometer.

\section{General procedure}

Under standard conditions, $40 \mathrm{mM}$ precursor and $40 \mathrm{mM}$ nitrite were incubated at $37^{\circ} \mathrm{C}$ in 250 $\mathrm{mM}$ sodium phosphate buffer (NaP), $\mathrm{pH} 2.5$ (nitrosation mixture, total volume $5 \mathrm{ml}$ ). In preliminary runs, the $\mathrm{pH}$ of the reaction mixture was measured and adjusted to the desired $\mathrm{pH}(2.5-3.7)$ with $1 \mathrm{M} \mathrm{HCl}$ or $\mathrm{NaOH}$ for each precursor and concentration. The amount required was recorded and added to the nitrosation mixture. For the investigation of the role of phosphate ions, $\mathrm{HCl}$ alone was used to adjust the $\mathrm{pH}$ value of precursor and nitrite. At time intervals of 5-10 min (= nitrosation time), a 1-ml aliquot was removed and added to a solution of $50 \mathrm{mg} \mathrm{NBP}$ in $3 \mathrm{ml}(0.5 \mathrm{ml}$ acetone, $2 \mathrm{ml}$ ethylene glycol and $0.5 \mathrm{ml} 1 \mathrm{M}$ sodium phosphate buffer, $\mathrm{pH} 8.1$ ) to give a neutral $\mathrm{pH}$ (alkylation mixture, total volume $4 \mathrm{ml}$ ). The concentration of NBP at the start of the second incubation was $58 \mathrm{mM}$. Nitrite was not destroyed, on the assumption that nitrosation would be negligible at $\mathrm{pH} 7$. The neutral mixture was incubated at $37^{\circ} \mathrm{C}$. Aliquots of $0.8 \mathrm{ml}$ were removed at various time intervals (= alkylation time), 0.2 $\mathrm{ml}$ triethylamine was added and the absorption maximum as well as the absorbance at $580 \mathrm{~nm}$ were recorded after $30 \mathrm{~s}$. Under these conditions, the colour of the NBP adducts was either pinkviolet or blue.

\section{Reaction profile}

By varying nitrosation and alkylation times in the test system described above, reaction 'profiles' were recorded to gain information on appropriate concentrations and reaction times for the subsequent experiments.

\section{Half-life of alkylating activity}

The half-life of the alkylating activity of the NOC was determined at acidic and neutral $\mathrm{pH}$. Appropriate concentrations were chosen from the reaction profiles and are shown in Table 1. Halflife in acid: Nitrite was destroyed after the nitrosation period by addition of an equimolar amount of $1.2 \mathrm{M}$ amidosulphonic acid in an aqueous solution which had been brought to $\mathrm{pH} 2.5$ by adding $1 \mathrm{M} \mathrm{NaOH}$. The $\mathrm{pH}$ of the mixture was measured. At different time intervals, an aliquot of $1 \mathrm{ml}$ was removed and added to $3 \mathrm{ml} \mathrm{NBP}$ solution as 
described above. The alkylation time was chosen from the reaction profiles to give near-maximum amount of NBP adduct. Half-life at $p H$ 7: The nitrosation mixture $(6 \mathrm{ml})$ was brought to $\mathrm{pH} 7$ by adding $3 \mathrm{ml} 1 \mathrm{M} \mathrm{NaP}, \mathrm{pH} 8$. Nitrite was not destroyed. The $\mathrm{pH}$ was measured. At different time intervals an aliquot of $1.5 \mathrm{ml}$ was removed and added to $2.5 \mathrm{ml}$ NBP solution which did not contain the NaP buffer (in contrast to the general procedure). The alkylation time was the same as for the determination of the half-life at acidic $\mathrm{pH}$.

\section{Nitrosation rates}

For the determination of the initial nitrosation rate it was necessary to use very short nitrosation times (up to $80 \mathrm{~s}$ if still linear) in order to avoid interference by decomposition of the nitrosated compounds. After $20,40,60 \mathrm{~s}$ a $1-\mathrm{ml}$ aliquot of the nitrosation mixture was removed and added to the NBP solution according to the general procedure. The same alkylation time was chosen as for the determination of the half-life. For concentrations see Table 2. This analysis was also used for the investigation of the reaction order for nitrite.

\section{Molar extinction coefficient of alkylated NBP}

Various concentrations of NBP (0.01-0.07 mM) were incubated at $37^{\circ} \mathrm{C}$ with a large excess of $\mathrm{ICH}_{3}(650 \mathrm{mM})$ or $\mathrm{ICH}_{2} \mathrm{COOH}(540 \mathrm{mM})$ in acetone dried before use over $\mathrm{MgSO}_{4}$. At different time intervals an aliquot of $0.8 \mathrm{ml}$ of the reaction mixture (or $0.4 \mathrm{ml}+0.4 \mathrm{ml}$ acetone) was added to $0.2 \mathrm{ml}$ of triethylamine and the absorbance at 580 $\mathrm{nm}$ was measured. When the absorbance reached a plateau, $100 \%$ reaction of NBP with the alkylating compound was assumed. A molar extinction coefficient was calculated from the plateau absorbance.

\section{Reactions with competing nucleophiles}

0.5 or $2.5 \mathrm{mM}$ amino acid or peptide [C] was incubated with different concentrations of nitrite (40-110 mM). After a nitrosation period adequate to allow virtually $100 \%$ of the precursor to be nitrosated (Asp: $40 \mathrm{~min}$; aspartame: $20 \mathrm{~min}$; GlyEE: $10 \mathrm{~min}$; see reaction profiles (Fig. 1); $[\mathrm{NOC}]=[\mathrm{C}]$ ) an aliquot of $1 \mathrm{ml}$ was added to 58 or $116 \mathrm{mM} \mathrm{NBP}$ at $\mathrm{pH} 7$. The alkylation mixture was incubated until the reaction reached a plateau (Asp and aspartame). For GlyEE, the alkylation period was limited to $3 \mathrm{~min}$, because of the instability of the NBP adduct. The absorbance was converted to the concentration of alkylated NBP using a molar extinction coefficient of 31000 , and the percentage of NOC that had reacted with NBP was calculated.

\section{DNA-binding study in the rat}

This experiment followed the principles described by Huber and Lutz (1984).

\section{Radiolabelled precursor}

$\left[1-{ }^{14} \mathrm{C}\right]$ Glycine ethylester from New England Nuclear had a specific activity of $50 \mathrm{mCi} /$ mmole. The ethanol solvent was evaporated with a slow stream of nitrogen after addition of a few drops of $250 \mathrm{mM}$ phosphoric acid. Sodium phosphate

TABLE 1

REACTION CONDITIONS AND HALF-LIVES OF ALKYLATING ACTIVITY AT ACIDIC AND NEUTRAL PH AFTER NITROSATION OF AMINO ACIDS AND DERIVATIVES

\begin{tabular}{|c|c|c|c|c|c|c|c|}
\hline \multirow[t]{3}{*}{ Precursor } & \multicolumn{5}{|c|}{ Reaction conditions } & \multicolumn{2}{|c|}{ Half-life (min) } \\
\hline & \multicolumn{3}{|c|}{ Conc. (mM) } & \multicolumn{2}{|l|}{ Time (min) } & \multirow[t]{2}{*}{ pH 2.5} & \multirow[t]{2}{*}{$\mathrm{pH} 7.0$} \\
\hline & Amine & Nitrite & NBP & Nitrosation & Alkylation & & \\
\hline Asp & 40 & 46 & 116 & 20 & 30 & $500^{a}$ & 60 \\
\hline Aspartame & 1 & 48 & 58 & 20 & 20 & 200 & 15 \\
\hline Gly & 116 & 171 & 116 & 10 & 10 & 35 & 3 \\
\hline GlyEE & 5 & 40 & 116 & 2 & 10 & 30 & 2 \\
\hline Ala & 80 & 133 & 116 & 15 & 5 & 40 & 2 \\
\hline
\end{tabular}

${ }^{\mathrm{a}} \mathrm{pH}=3.5$. 
buffer (250 mM, pH 2.5) was added to give a specific radioactivity of the application solution of $1.5 \times 10^{8} \mathrm{dpm} / \mathrm{g}$. Radiochemical purity, as checked by radio thin-layer chromatography, was $>97 \%$.

\section{Animals and treatments}

Male Sprague-Dawley rats (Iva:SIV-50.SD) from Ivanovas, Kissleg (F.R.G.), were housed in macrolone cages and given free access to food (Laboratory chow No. 343, Klingenthal Mühle AG, Kaiseraugst, Switzerland) and tap water for an acclimatisation period of 1 week. The rats were not fasted prior to p.o. application of the test substance. GlyEE was administered first, followed immediately by sodium nitrite dissolved in 250 $\mathrm{mM}$ sodium phosphate buffer, $\mathrm{pH}$ 2.5. The total volume given to each rat was $2 \mathrm{ml}$. Exact doses administered to individual animals are shown in Table 3. Two rats received GlyEE without nitrite in order to control for the incorporation of radiolabel into DNA at background levels of nitrosation. Two untreated rats served as controls for radiolabelled contaminations. After $30 \mathrm{~min}$, the rats were killed by heart puncture under ether anaesthesia. Stomach and liver were removed from each rat. The stomachs were sliced open and rinsed in $10 \mathrm{ml}$ saline solution to remove contents.

\section{Isolation of DNA and analysis of DNA nucleotides}

DNA was isolated from a chromatin pellet according to Sagelsdorff et al. (1983). The nucleo- tide analysis was performed according to Sagelsdorff et al. (1988). For the repetitive purification performed on 1 liver sample, the DNA was extracted with phenol/chloroform/iso-amylalcohol and with diethylether, and was dialysed before precipitation with ethanol. The specific activity did not decrease between the second and the third round of purification.

\section{Results}

NBP test

\section{Reaction profiles}

Fig. 1 shows the rate of NBP alkylation by nitrosated precursors as a function of both the nitrosation period ( $\mathrm{pH} 3.4$; $\mathrm{x}$-axis) and the alkylation period ( $\mathrm{pH} 7$; different curves). With aspartic acid (Fig. 1A), it can be seen that the formation of alkylating species was nearly complete after 20 min, that the alkylating species was stable at $\mathrm{pH}$ 3.4 , and that the alkylation reaction was relatively slow, as indicated by a doubling of the amount of NBP adducts formed between 30 and $90 \mathrm{~min}$ alkylation time. Both nitrosation and alkylation reactions are faster with aspartame (Fig. 1B). Nitrosation of aspartame reached a plateau at $\leqslant 10 \mathrm{~min}$. The alkylating activity after nitrosation of aspartame again was stable at acidic $\mathrm{pH}$. When brought to $\mathrm{pH} 7$ and incubated with NBP, the reaction was completed after $25 \mathrm{~min}$. An alkylation period of $50 \mathrm{~min}$ produced the same ab-
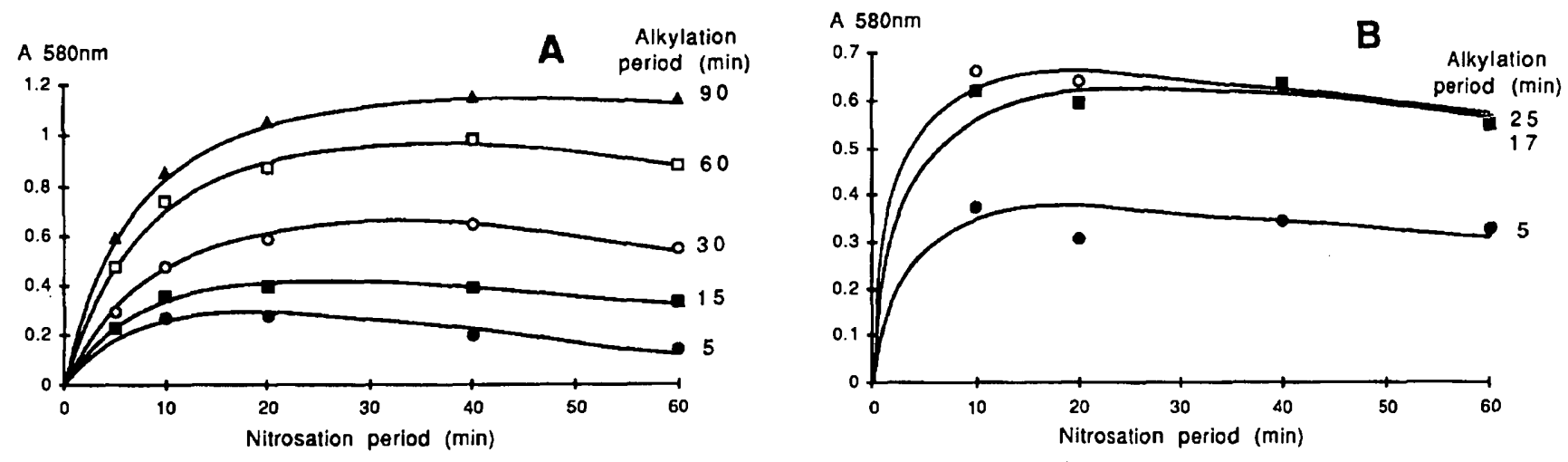

Fig. 1. Formation of NBP adducts as a function of time with nitrosated aspartic acid (A) and aspartame (B). x-axis: nitrosation period at $\mathrm{pH} \mathrm{3.4;} \mathrm{different} \mathrm{curves:} \mathrm{alkylation} \mathrm{period}(\mathrm{min})$ with $\mathrm{NBP}$ at $\mathrm{pH} 7$. The absorbance at $580 \mathrm{~nm}$ is measured immediately after bringing the incubate to $\mathrm{pH}>10$. Concentrations used: (A), Asp $80 \mathrm{mM}$, nitrite $80 \mathrm{mM}$, NBP $58 \mathrm{mM}$; (B), aspartame $5 \mathrm{mM}$, nitrite $46 \mathrm{mM}$, NBP $58 \mathrm{mM}$. 

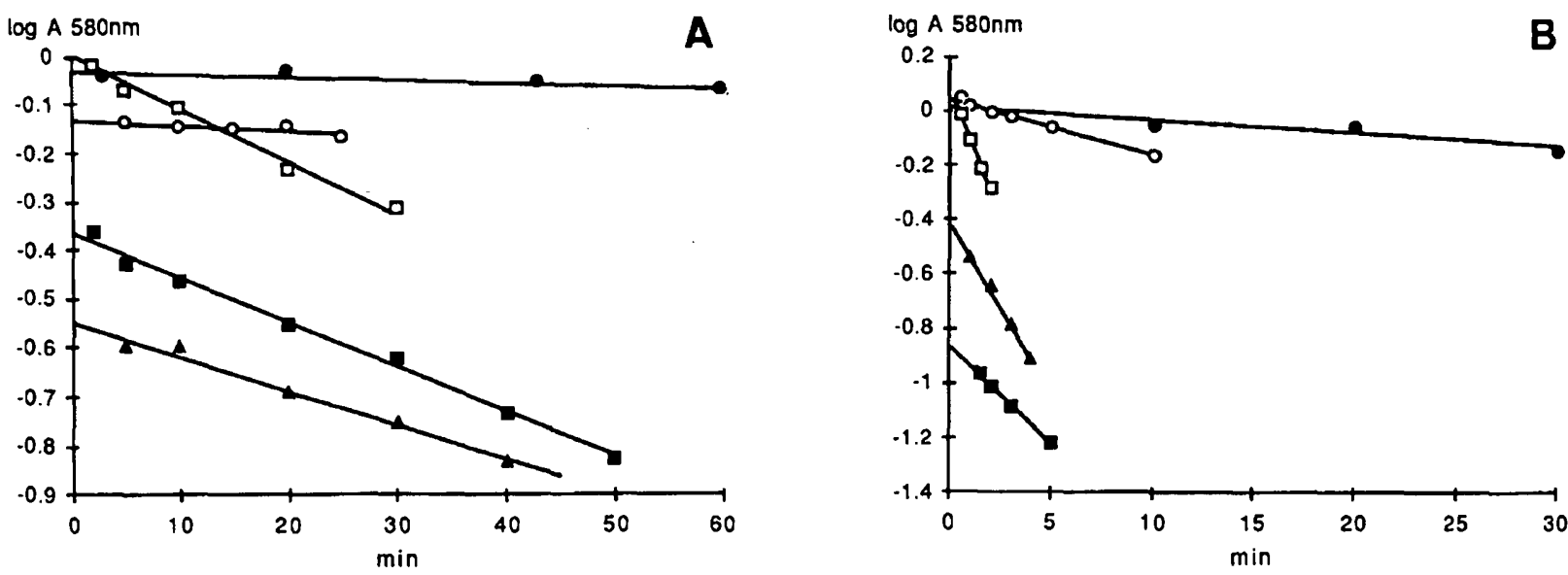

Fig. 2. Decay of alkylating activity under acidic conditions (A) or at pH 7 (B) after nitrosation of (•) Asp (pH 3.5), (O) aspartame, (a) Gly, () GlyEE, and (A) Ala (all at pH 2.5). Alkylating intermediates trapped with NBP.

sorbance as with $25 \mathrm{~min}$ (data not shown). This indicates that these NBP adducts were stable within our period of observation. With GlyEE, the absorbance values showed a maximum at $\leqslant 3 \mathrm{~min}$ alkylation period and decreased with longer times. This indicates that the NBP adduct formed by nitrosated GlyEE was not as stable as those of Asp and aspartame (data not shown).

\section{Half-life of alkylating activity}

The stability of the alkylating activity of nitrosated precursors at acidic and neutral $\mathrm{pH}$ can be derived from Fig. 2, which shows NBP adduct formation as a function of the interval between stopping the nitrosation reaction and the addition of NBP. The data were analysed by linear regression, assuming first-order kinetics, and the half- lives are compiled in Table 1. All precursors showed an alkylating activity that was more stable at acidic $\mathrm{pH}$ than at neutral $\mathrm{pH}$. The most striking feature was the astonishing stability of the alkylating intermediates of nitrosated Asp and aspartame (half-lives of 500 and $200 \mathrm{~min}$ in acid, 60 and 15 min at neutral $\mathrm{pH}$ ).

\section{Nitrosation rates}

Analysis of the first minute of the reaction shown in Fig. 1 was used to determine the reaction rate. The absorbance increased linearly with time up to $80 \mathrm{~s}$. The reaction rate for various precursors is expressed as $\Delta \mathrm{A} / \mathrm{s}$ in column 4 of Table 2. For a conversion of these data to nitrosation rate constants $k_{2}$ defined by Mirvish (1975), (i) the absorbance values must be converted to

TABLE 2

REACTION CONDITIONS AND CALCULATION OF THE NITROSATION RATE CONSTANTS FOR ASPARTIC ACID, ASPARTAME AND GLYCINE ETHYLESTER

\begin{tabular}{|c|c|c|c|c|c|c|}
\hline & \multicolumn{2}{|c|}{ Conc. (M) } & \multirow[t]{2}{*}{$\mathrm{pH}$} & \multirow{2}{*}{$\begin{array}{l}\text { Reaction rate } \\
A(580 \mathrm{~nm}) / \mathrm{s}\end{array}$} & \multirow{2}{*}{$\begin{array}{l}\text { Fraction of NOC } \\
\text { reacting with NBP }\end{array}$} & \multirow{2}{*}{$\begin{array}{l}k_{2} \\
\left(\mathrm{M}^{-2} \mathrm{~s}^{-1}\right)\end{array}$} \\
\hline & Amine & Nitrite & & & & \\
\hline Asp & 0.07 & 0.11 & 3.7 & 0.03 & 0.015 & 0.08 \\
\hline Aspartame & 0.003 & 0.07 & 3.2 & 0.05 & 0.08 & 1.4 \\
\hline GlyEE & 0.005 & 0.04 & 2.5 & 0.02 & $\geqslant 0.45^{a}$ & $0.2^{\mathrm{a}}$ \\
\hline
\end{tabular}

\footnotetext{
Limit value (instability of NBP adduct).

$k_{2}=\frac{\mathrm{A} / \mathrm{s}}{31000 \cdot \text { fraction of NOC } \cdot[\text { amine }] \cdot[\text { nitrite }]^{2}}$
} 
chemical concentrations, and (ii) competing reactions with nucleophiles other than NBP must be taken into account. For this purpose, the following data had to be collected.

\section{Molar extinction coefficient of alkylated NBP}

When NBP was incubated with a large excess of either methyl iodide or iodoacetic acid in acetone and aliquots were taken at different times, a plateau was reached after about $30 \mathrm{~min}$, indicating $100 \%$ adduct formation. Using the known NBP concentration in the incubate, a molar extinction coefficient was derived from the absorbance values. Methylated NBP exhibited a molar coefficient of 30600 , carboxymethylated NBP a coefficient of 31600 . Since the presence of the carboxylic acid moiety did not have a significant effect on the extinction coefficient, an average value of 31000 was used for all subsequent calculations.

\section{Reactions with competing nucleophiles}

The ultimate alkylating agent(s) derived from the nitroso amino acids react not only with NBP but also with competing nucleophiles, including water. The fraction reacting with NBP must be known for a calculation of the nitrosation rate. By incubating a small concentration of precursor $\mathrm{C}$ with a much higher concentration of nitrite, $100 \%$ precursor can be nitrosated, so that the concentration of NOC equals the concentration of $\mathrm{C}$. The alkylation reaction at $\mathrm{pH} 7$ with NBP was brought to completion in a similar way. The maximum level of coloured product formed was compared with the known concentration of NOC, and the fraction of NOC that had reacted with NBP was calculated. Values ranged from 1.5 to $\geqslant 45 \%$ (column 5 in Table 2). The values derived for GlyEE (45\%) must be considered a lower limit value because of the instability of the NBP adduct (half-life about $7 \mathrm{~min}$ at $\mathrm{pH} \mathrm{7;} \mathrm{data} \mathrm{not} \mathrm{shown).}$

\section{TABLE 3}

RADIOACTIVITY IN DNA ISOLATED FROM STOMACH AND LIVER OF MALE RATS 30 min AFTER ORAL ADMINISTRATION OF $\left[{ }^{14} \mathrm{C}\right]$ GlyEE WITH AND WITHOUT SUBSEQUENT GAVAGE OF SODIUM NITRITE

\begin{tabular}{|c|c|c|c|c|}
\hline \multirow{2}{*}{$\frac{\text { Treatment }}{\text { Animal weight }(g)}$} & \multicolumn{2}{|c|}{ GlyEE + nitrite } & \multicolumn{2}{|c|}{ GlyEE alone } \\
\hline & 270 & 279 & 292 & 276 \\
\hline Chemical dose GlyEE (mg/kg b.w.) & 0.69 & 0.75 & 0.63 & 0.72 \\
\hline Radioactivity dose ( $\times 10^{8} \mathrm{dpm} / \mathrm{kg}$ b.w.) & 5.19 & 6.08 & 4.75 & 5.57 \\
\hline Dose sodium nitrite ( $\mu$ mole $/ \mathrm{kg} \mathrm{b.w.)}$ & 330 & 294 & - & - \\
\hline Time of administration & 8.00 a.m. & 1.00 p.m. & 8.00 a.m. & 1.00 p.m. \\
\hline \multicolumn{5}{|l|}{ Stomach $D N A$, 1st purification: } \\
\hline Amount in vial (mg) & 3.03 & 2.59 & 2.95 & 3.02 \\
\hline Gross activity (cpm) ${ }^{\mathrm{a}}$ & 56.8 & 42.0 & 32.6 & 37.1 \\
\hline Specific activity (dpm/mg) ${ }^{b}$ & 16.3 & 12.3 & 7.0 & 8.6 \\
\hline (CBI units) ${ }^{c}$ & 9.7 & 6.2 & 4.8 & 4.6 \\
\hline \multicolumn{5}{|l|}{ Liver $D N A, 1$ st purification: } \\
\hline Amount in vial (mg) & 0.74 & 0.88 & 0.99 & 0.77 \\
\hline Gross activity (cpm) $^{a}$ & 66.2 & 21.4 & 35.1 & 19.8 \\
\hline Specific activity (dpm/mg) ${ }^{b}$ & 80.5 & 7.5 & 22.6 & 6.0 \\
\hline (CBI units) ${ }^{c}$ & 48 & 4 & 15 & 3 \\
\hline \multicolumn{5}{|l|}{ Repetitive DNA purification: } \\
\hline Constant specific activity $(\mathrm{dpm} / \mathrm{mg})^{b}$ & 46 & & & \\
\hline$\quad$ (CBI units) $^{c}$ & 27 & & & \\
\hline DNA adducts ${ }^{d}$ & $\leqslant 3$ & & & \\
\hline
\end{tabular}

aNA isolated from control rat: $15.6 \mathrm{cpm}$.

b Counting efficiency: $84 \%$.

c $\mathrm{CBI}=(\mu$ mole GlyEE per mole DNA nucleotide $) /($ mmole GlyEE dosed per kg b.w.).

d From nucleotide analysis. 
Even when using short reaction periods for the alkylation (3 $\mathrm{min}$ ), some NBP adducts formed have already decayed.

\section{Reaction order for nitrite}

When incubated with different concentrations of nitrite, the rate of reaction increased with the square of nitrite concentration with all precursors, as observed by Mirvish (1975) for secondary alkyl amines.

\section{DNA binding in the rat}

A comparison of the animals given GlyEE and nitrite with the controls given GlyEE alone shows that the presence of $10-30 \mathrm{mM}$ nitrite in the stomach had very little effect on the amount of radioactivity associated with the stomach DNA (Table 3). Normalised to the dose of radiolabel
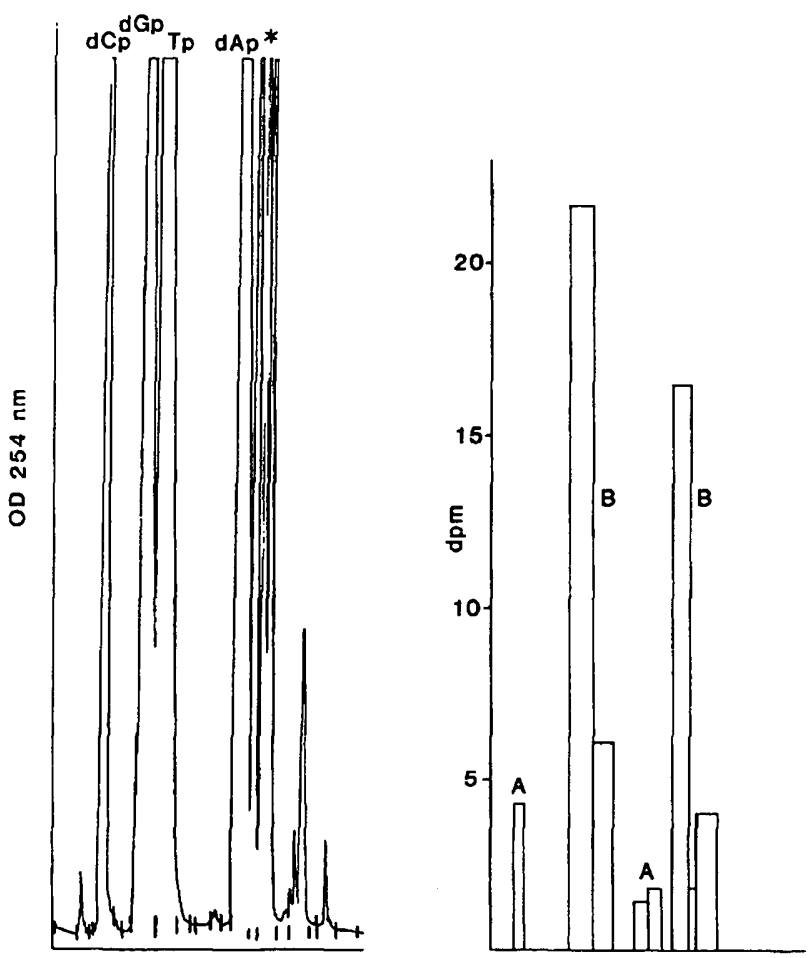

Fig. 3. HPLC analysis of nucleotides of liver DNA isolated from male rats $30 \mathrm{~min}$ after oral administration of $\left[{ }^{14} \mathrm{Clglycine}\right.$ ethylester and nitrite. Radioactivity (right-hand chart) eluting in optically dense fractions (see left-hand chart) is designated with the letter B (bioincorporation of radiolabel into normal nucleotides by de novo biosynthesis, or hidden DNA adducts). Radioactivity eluting with little or no optical density is designated with the letter $A$ (potential DNA adducts). administered, there was no significant difference in the specific activity of DNA isolated from the stomach (expressed in the units of the covalent binding index, CBI; Lutz, 1979). The specific radioactivity on the stomach DNA was too low to allow the precise amount of adduct formation to be confirmed by nucleotide analysis. In the liver, the DNA samples obtained from the animals dosed at 8.00 a.m. had higher specific activities (diurnal variation in DNA synthesis). One sample could be analysed for covalently bound radioactivity (DNA adducts) and biosynthetic incorporation of radiolabel from GlyEE or metabolites into the DNA. DNA was broken down to the nucleotides and the natural nucleotides were separated from putative adducts by high-performance liquid chromatography (HPLC). The absorbance at $254 \mathrm{~nm}$ and the radioactivity histogram of the nucleotide analysis are shown in Fig. 3. The four largest peaks represent the natural nucleotides, eluting in the order $\mathrm{dCp}, \mathrm{dGp}, \mathrm{dTp}$ and $\mathrm{dAp}$. The radioactivity that co-eluted with the natural nucleotides (B) amounted to $90 \%$ of the total radioactivity and was probably due to biosynthetic labelling of the DNA. Only $10 \%$ of the radioactivity (about 5 $\mathrm{dpm} / \mathrm{mg}$ ) that eluted at other times with little or no absorbance (A) could be due to DNA adduct formation. The absolute values of radioactivity in these fractions were at the limit of detection $(<5$ dpm!) so that it would be premature to conclude DNA adduct formation from the present results.

\section{Discussion}

We have shown that the nitrosation of $\alpha$-amino acids results in the formation of derivatives which can alkylate nucleophiles without metabolic activation. These derivatives will later be called nitroso compounds ('NOC') although we do not have structural evidence for the nitrosated molecules.

Our main interest was in the alkylating activity of the nitrosated compounds as this represents the most relevant parameter in toxicology. Our data indicate that the nitrosation reaction has the same kinetics as for alkylamines (Mirvish, 1975), both with respect to the quadratic dependence on the concentration of nitrite and to the inverse relationship of the nitrosation rate with the basicity: 
$\mathrm{dNOC} / \mathrm{dt}=k_{2} \cdot[\mathrm{C}] \cdot[\text { nitrite }]^{2}$. Because only the protonated form of nitrite and the unprotonated form of the precursor $\mathrm{C}$ are reactive, the $\mathrm{k}_{2}$ value is $\mathrm{pH}$-dependent. With the low $\mathrm{p} K_{\mathrm{a}}$ of aspartame's amino group $\left(\mathrm{p} K_{\mathrm{a}}=7.7\right.$ as determined in this laboratory) this compound has a relatively high nitrosation rate constant $\left(k_{2}=1.4\right.$ at $\left.\mathrm{pH} 3.2\right)$. Nevertheless, the formation of 'nitrosoaspartame' under standard conditions of artificial sweetening (assumed initial concentration in stomach: $1 \mathrm{mM}$ ) and in the presence of $5 \mu \mathrm{M}$ nitrite will only be in the order of nanograms, i.e., negligible in comparison with the intake of preformed nitroso compounds (Preussmann and Eisenbrand, 1984).

Although nitrosation of primary alkylamines is known to generate highly unstable 'NOC', the alkylating activity after nitrosation of some amino acids as determined in the NBP test was astonishingly persistent, higher under acidic conditions than at neutral $\mathrm{pH}$. This $\mathrm{pH}$ dependence would not be expected for the diazonium ion, the most probable ultimate alkylating agent (Challis et al., 1987). For the amino acids tested it could be postulated that the rate-limiting step of the reaction sequence is the conversion of the primary 'NOC' to the diazonium ion or that other forms exist which stabilise the alkylating moiety. The latter hypothesis can be dismissed with respect to the possibility of phosphate ester formation: control experiments run with aspartic acid in the absence of phosphate buffer showed no difference in stability of the alkylating activity.

The persistence of the alkylating activity seems to be sufficient to allow a diffusion not only into the stomach lining cells but possibly also to other organs, such as the liver. However, the stability in vivo will depend upon the presence of catalysts and inhibitors for the various steps and on the presence of reactive nucleophiles. Therefore, studies with biological endpoints are required.

The properties of some of the compounds investigated in the Ames test have been described (Shephard et al., 1987a). Both aspartame and glycine ethylester were potent mutagens after nitrosation. The present investigation of the in vivo DNA-binding potency of glycine ethylester plus nitrite shows that the in vitro data cannot be extrapolated to the situation in an animal on a quantitative basis. The amount of 'NO-GlyEE' was estimated on the basis of the reaction rate and the concentrations of the reactants at the time of the administration, using a simulation program (Stella, Macintosh) and several assumptions (stomach volume in the rat: $3-4 \mathrm{ml}$; half-life of nitrite in the stomach: $10 \mathrm{~min}$; half-life of 'GlyEE': $30 \mathrm{~min}$ ). A conversion of $6 \%$ 'GlyEE' to 'NOGlyEE' would have resulted under these conditions. The analysis of DNA isolated from the stomach or the liver did not reveal DNA adducts at a limit of detection of $\mathrm{CBI}<3$ for GlyEE, and of $\mathrm{CBI} \leqslant 50$ ( 3 divided by 0.06 ) for 'NO-GlyEE'. The methylating potency of $N$-nitrosomethylurea in stomach after oral administration is in the order of $\mathrm{CBI} \approx 300$ (Lutz, 1979). Therefore, 'NO-GlyEE' appears to be much less dangerous with respect to stable alkylation of stomach DNA, in contrast to the effects expected on the basis of the in vitro data (Shephard et al., 1987a). The protection of the DNA in vivo can be due to a number of causes. One reason is an effective detoxification by reaction with nucleophiles better than DNA. Alternatively, the DNA adducts formed by 'NOGlyEE' might not be completely stable. The most nucleophilic center in double-stranded DNA is the nitrogen no. 7 of guanine. The electronic configuration is similar to the pyridine nitrogen of NBP. Since the NBP adduct formed with 'NO-GlyEE' was not stable this hypothesis cannot be rejected.

Our data show that in vitro studies are useful for the analysis of the kinetics of the nitrosation and alkylation reactions. However, any risk evaluation must still be based upon in vivo experiments.

\section{References}

Brambilla, G., M. Cavanna, P. Carlo, R. Finollo, L. Sciaba, S. Parodi and C. Bolognesi (1979) DNA damage and repair induced by diazoacetyl derivatives of amino acids with different mechanisms of cytotoxicity. Correlations with mutagenicity and carcinogenicity, J. Cancer Res. Clin. Oncol., 94, 7-20.

Challis, B.C., M.H.R. Fernandes, B.R. Glover and F. Latif (1987) Formation of diazopeptides by nitrogen oxides, IARC Sci. Publ. 84, International Agency for Research on Cancer, Lyon, pp. 308-314.

Huber, K.W., and W.K. Lutz (1984) Methylation of DNA in stomach and small intestine of rats after oral administration of methylamine and nitrite, Carcinogenesis, 5, 17291732. 
Lutz, W.K. (1979) In vivo covalent binding of organic chemicals to DNA as a quantitative indicator in the process of chemical carcinogenesis, Mutation Res., 65, 289-356.

Mirvish, S.S. (1975) Formation of $N$-nitroso compounds: chemistry, kinetics, and in vivo occurrence, Toxicol. Appl. Pharmacol., 31, 325-351.

Pollock, J.R.A. (1985) Formation of nitrosoiminodialkanoic acids during the nitrosation of peptides, Food Chem. Toxicol., 23, 701-704.

Preussmann R., and G. Eisenbrand (1984) N-Nitroso carcinogens in the environment, Am. Chem. Soc. Monogr., 182 829-868.

Sagelsdorff, P., W.K. Lutz and C. Schlatter (1983) The relevance of covalent binding to mouse liver DNA to the carcinogenic action of hexachlorocyclohexane isomers, Carcinogenesis, 4, 1267-1273.

Sagelsdorff, P., W.K. Lutz and C. Schlatter (1988) DNA methylation in rat liver by daminozide, 1,1-dimethylhydrazine, and dimethylnitrosamine, Fund. Appl. Toxicol., 11, 723730.
Shephard, S.E., M.E. Hegi and W.K. Lutz (1987a) In-vitro assays to detect alkylating and mutagenic activities of dietary components nitrosated in situ, IARC Sci. Publ. 84, International Agency for Research on Cancer, Lyon, pp. 232-236.

Shephard, S.E., C. Schlatter and W.K. Lutz (1987b) Assessment of the risk of formation of carcinogenic $N$-nitroso compounds from dietary precursors in the stomach, Food Chem. Toxicol., 25, 91-108.

Tricker, A.R., and R. Preussmann (1986) Formation of $N$ nitrosoiminodialkanoic acids and their unsuitability as biological monitors for endogenous nitrosation of dipeptides, Carcinogenesis, 7, 1523-1526.

Warthesen, J.J., R.A. Scanlan, D.D. Bills and L.M. Libbey (1975) Formation of heterocyclic $N$-nitrosamines from the reaction of nitrite and selected primary diamines and amino acids, J. Agric. Food Chem., 23, 898-902. 